\title{
Erratum to: Genetic engineering for peanut improvement: current status and prospects
}

\author{
Garladinne Mallikarjuna $^{1}$ - Tata Santosh Rama Bhadra Rao ${ }^{1}$ P. B. Kirti ${ }^{2}$
}

Published online: 29 March 2016

(C) Springer Science+Business Media Dordrecht 2016

\section{Erratum to: Plant Cell Tiss Organ Cult \\ DOI 10.1007/s11240-016-0966-9}

The last author's name showed incorrectly in the initial online publication. The author's name has been corrected in the online publication (and shows correctly in this erratum too).

The online version of the original article can be found under doi:10.1007/s11240-016-0966-9.

Garladinne Mallikarjuna garladinnemarjun@gmail.com

1 Agri Biotech Foundation, Rajendranagar, Hyderabad 500030, India

2 Department of Plant Sciences, School of Life Sciences, University of Hyderabad, Hyderabad 500046, India 